\title{
RESEARCH ON THE DIFFUSION OF AGRICULTURAL INNOVATIONS IN THE UNITED STATES AND THE NETHERLANDS
}

\author{
by \\ EVERETT M. ROGERS \\ The Obio State University \\ Columbus, Obio, U.S.A. \\ and \\ ANNE W. VAN DEN BAN \\ Agricultural University \\ Wageningen, The Netherlands
}

Of six research traditions on the diffusion of innovations (anthropology, early sociology, rural sociology, education, industrial, and medical sociology) recently analyzed, the rural sociology tradition has produced the greatest number of publications and studies on the diffusion of new ideas (Rogers, 1962). A research tradition is a series of research studies on a similar topic in which successive studies are influenced by those preceding. The purpose of the present paper is to provide a comparative analysis of two sub-traditions within rural sociology, the research on diffusion that has occurred ( $I$ ) in the United States, and (2) in the Netherlands. Emphasis will be placed upon the historical development of the field in both countries and upon the differences in research methods. Somewhat greater attention is given to Netherlands' research which is relatively unknown outside that country, because of language barriers.

\section{HISTORICAL DEVELOPMENT}

\section{United States}

The tural sociology diffusion research tradition began in the I920's when administrators in the U.S. Department of Agriculture Federal Extension Service instigated evaluations of their program's effective- 
ness (summarized by Wilson and Gallup, 1955). One handy evaluation measure was the adoption of farm and home innovations promoted by the Extension Service.

Little further research was completed in this tradition until the I940's when Kollmorgen (I94I) investigated the adoption of new farm ideas by German-Swiss farmers in Tennessee, Hoffer (1942) studied the adoption of celery-growing practices by Michigan farmers of Dutch descent and Ryan and Gross (1943) analyzed the diffusion of hybrid seed corn in Iowa. The classic study by Ryan and Gross is undoubtedly one of the most widely-known rural sociological studies of all time; more than any other study, it influenced the methods, findings, and interpretations of later students in the rural sociology tradition in the U.s. and elsewhere.

Since the mid-r950's, a proliferation of diffusion research studies has occurred.

The considerable amount of diffusion research in the U.s. has led recently to two different books that aim to summarize and integrate the findings (Lionberger, I960; Rogers, I962).

\section{The Netherlands}

Diffusion research in the Netherlands originally 'diffused' from the United States, but has since grown into a somewhat different progeny than its intellectual ancestors. In the present paper we stress these differences more than the many American examples of diffusion research which have been followed in the Netherlands. In 1950, Professor E. W. Hofstee, head of the Department of Rural Sociology at the Agricultural University of Wageningen, made a study tour of U.s. land-grant universities under the sponsorship of the Marshall Plan. He was impressed by research on the adoption of new farm practices at Michigan State University and at several other universities. The following year he stressed this topic in a Netherlands lecture on urgent research problems in rural sociology. Van den Ban selected the adoption of innovations as a topic for his Master's thesis at Wageningen from the topics mentioned in Hofstee's lecture. Several other graduate students followed this example, and Hofstee utilized their findings in a lecture to the Extension Service to show the importance of diffusion research. As a result, in 1954 and 1955 , Wichers and Van den Ban were detached by the Netherlands Ministry of Agriculture to the Department of Rural Sociology in Wageningen to conduct sociological research for the Extension Service. Similar 
research is now also underway by some rural development agencies and at the Socio-Economic Research Department of the Agricultural Economics Research Institute in the Hague.

\section{SIMILARITIES AND DIFFERENCES}

\section{Information Sources by Adoption Process Stages}

The adoption process is the mental process through which an individual passes from first hearing about an innovation to final adoption. Most researchers have conceptualized the adoption process in terms of five stages or steps. At the awareness stage the individual is exposed to the innovation but lacks complete information about it. He then becomes interested in the innovation and seeks information about it at the interest stage. At the evaluation stage the individual mentally applies the innovation to his present and anticipated future situation, and then decides whether or not to try it. The individual uses the innovation on a small scale in order to determine its utility in his own situation at the trial stage. At the adoption stage the individual decides to continue the full use of the innovation. Evidence from research studies in the U.S. indicates the conception of adoption stages is probably valid (Rogers, I962).

Personal communications involve a direct face-to-face exchange between the communicator and communicatee. Impersonal information sources (such as mass media) are most important at the awareness stage, and personal sources are most important at the evaluation stage in the adoption process. Cosmopolite information sources (originating from sources external to the social system) are most important at the awareness stage, and localite sources are most impottant at the evaluation stage.

\section{Adopter Categories}

Adopter categories are the classification of individuals within a social system on the basis of innovativeness. Although a variety of categorization systems and titles for adopter categories have been utilized in past research studies in the United States, one method of categorization (Rogers, I958) has recently gained some acceptance and offers potential for greater standardization of research methods and a. more meaningful comparison of findings from one study to another. The continuum of innovativeness is partitioned into five adopter 
categories (innovators, early adopters, early majority, late majority, and laggards) on the basis of the two parameters of the normal distribution, the mean and the standard deviation.

The five adopter categories should be viewed as ideal types, conceptualizations based on observations of reality and designed to institute comparisons. Many research studies in the United States (Rogers, 1962) have investigated the values and characteristics of adopter categories. The dominant values of each category may be synthesized as follows: innovators, venturesome; early adopters, respect; early majority, deliberate; late majority, sceptical; and laggards, tradition. The relatively earlier adopters in a social system tend to be younger in age, have higher social status, a more favourable financial position, more specialized operations, and a different type of mental ability than later adopters. Innovators and early adopters use information sources that are more impersonal and cosmopolite than those used by late majority and laggards. The social relationship of innovators and early adopters are more cosmopolite than for laggards, and early adopters have more opinion leadership.

\section{Research metbods}

Similarly to American researchers, Dutch rural sociologists have investigated the social characteristics of adopter categories. Naturally, these characteristics are interrelated. In the United States, this problem has usually been solved by multiple correlation analysis; in the Netherlands, however, factor analysis has recently been employed (Van den Ban, I963). Multiple correlation analysis determines the influence on the dependent variable of one independent variable at a time, keeping the other independent variables constant. Factor analysis, on the other hand, does not distinguish between dependent and independent variables, but tells us to what extent variables vary together (Hofstätter; in König, I962, pp. 385-414). It is somewhat unrealistic to study the influence of farm size on innovativeness while keeping education and social status constant. Large-scale farmers with low education and low social status are an exceptional type. If other factors are left constant, one compares an exceptional type of largescale farmers with small farmers who are also exceptional, because they have high education and social status. For these reasons, factor analysis is useful in the analysis of interrelationship between the social characteristics of adopter categories. 


\section{Norms}

It is not only the task of sociologists to explain individual behaviour, as in the case of characteristics of adopter categories, but also to explain group behaviour. Differences in innovativeness between locality groups of farmers are much more important in the Netherlands than in the United States. In the Netherlands, farmers living only ten miles apart may have a very different sub-culture and style of farming. Several studies have been completed of differences between 'high adoption' (or modern) and 'low adoption' (or traditional) communities. In two studies these community norms on innovativeness were measured with the question: "What do people in this village think generally of a farmer who is usually one of the first to adopt a new practice?' The answers proved to be unrelated to the innovativeness of the respondents, but in a 'high adoption' community Is per cent answered 'unfavourable' and in a 'low adoption' community, 45 per cent (Van den Ban, I963). Similar results were obtained by Van de Sandt and Bauwens in an unpublished study by the Agricultural Economics Research Institute. In the case of the two studies first mentioned there was not much difference between the two communities in farm size, type of farming, education of farmers, or their socio-economic status. Also in communications research it is recently recognized that it is necessary to study not only the reactions of individuals, but also the differences in the reactions of members of different groups. A Dutch study by Brouwer (I962) illustrates this point.

This raises the question why there are norm differences in innovativeness among communities. These differences are probably related to differences in the total cultural patterns of the communities. These cultural patterns in the Netherlands have been studied by the participant observer method of the cultural anthropologist. Fortunately, in Europe, sociology and anthropology are not as widely separated as in the U.s. Many of the anthropological observations are confirmed by formal interviews. The combination of formal interviews with anthropological research methods is one distinction between European and U.s. rural sociological research (Wurzbacher, I954; Mendras, x958).

\section{Traditonal Farmers}

The culture of some Netherlands farmers is rather similar to Redfield's peasant culture. Their knowledge of what happens outside 
their own village is limited. Within their own village they do not select special friends, but talk regularly to everyone. Outsiders, however, and especially city and upperclass people, are ususally regarded with distrust. On their own farms the traditional farmers do not count depreciation, family labour, and other costs which do not involve cash expense. As a result, the family labour stays on the farm even when the remuneration is much lower than could be earned elsewhere. The traditional peasant keeps his expenses very low, and he will not assume any debts except for purchasing land (J. P. A. van den Ban, 196r).

Not all Dutch farmers have this kind of traditional culture; many are at least as modern as u.s. Corn Belt farmers. Otherwise, it would be impossible for a country with a population of about 350 people per square kilometer and only twelve per cent of its labout force engaged in agriculture to export 40 per cent of its gross agricultural production. In the Netherlands, and in much of Europe, there is probably a wider range between the traditional and modern farmer than in the U.S., or at least North Central u.s., where most rural sociological research is done.

Measurement of the differences between farmers with a modern culture and farmers with a traditional peasant culture has been attempted in the Netherlands. Benvenuti ( $(96 \mathrm{I}$ ) used a scale composed of to items which he coded to determine whether farmers had an opinion or not about extra-community issues, disregarding the kind of opinion they had. A typical Benvenuti-type question is: 'What do you think of the initiatives taken by Dutch political parties for the farmer's interest?' If a farmer gives an opinion on such an issue, he was assumed to be more modern than traditional. Indications that this assumption is correct give also Germani (1960) and Lerner (I958).

Benvenuti was not willing to accept the validity of his scale at face value, but used an interesting method to validate his traditionalismmodernism scale. A list of farmers scoring high on his scale and another list of those scoring low was given to a number of key informants who resided in the community and knew most of these farmers quite well. Each informant was asked to describe the individuals listed without being told how the researcher obtained these two lists. The informants agreed in describing the high scoring farmers as modern and the low scoring farmers as traditional peasants.

Bergsma ( 1963 ) retested Benvenuti's scale in another community with a somewhat more modern culture. His findings indicate that equally valid items may be asked as to farmer's actual knowledge of 
what happens outside of their village (e.g.: 'Do you know to which of the eight Dutch political parties the Minister of Agriculture belongs?'). Bergsma scored the number of correctly-answered questions to measure traditionalism-modernism.

If there are important differences in the cultural norms of rural communities and if these differences influence the diffusion of innovations, sociologists should study the causes of these norm differences. Dutch rural sociologists have mainly been looking for two kinds of explanation: isolation and social stratification. That geographical isolation may retard the acceptance of a modern cultuxal pattern is clear; this is also a finding from studies of several u.s. mountain areas. Groenman (I947) studied a Dutch village where people were resistant to adopt innovations, but which was not isolated. In fact, for many centuries there was a main road through the village connecting two urban centres. He explained the traditionalism of this village as due to its isolation by rivers and swamps from other rural villages. The urban culture was so much different from the village culture, that the villagers did not adopt many elements of urban culture. Now the swamps are reclaimed and there are contacts with other rural villages. But the cultural pattern of this village remains much more traditional than that of neighbouring villages, according to Groenman: the gap in the modernization of their culture is now so large that it is difficult to bridge. In this case, a sociologist made a historical study in order to explain the rate of diffusion of innovations in different cultural patterns. Few U.s. rural sociologists have used the historical approach until recently.

Wichers is attempting to give a more general explanation of the reasons why some communities are more traditional than others. In his present study, he is testing the hypothesis that the development of a traditional peasant culture is stimulated by a society with a rigid social structure and wide social distance between peasants and elite (feudal lords, upper class urbanites, etc.). Undet these conditions the possibilities for intellectual development are restricted to the elite, and the peasants, in order to maintain their dignity, place a high value on manual labour. One of the reasons which makes this possible for the peasants is that the intellectual development of the elite is usually more devoted to the classical tradition than to the solution of technological problems. The upperclass people in the rural society usually have some idea of the new culture which is developing in the cities, but the social distance between 
them and the peasants is so large that they do not communicate their ideas to the peasants.

In the Netherlands there is a good opportunity to test this hypothesis because only a part of the country has known feudal lords. In the northern part of the country farmers have always governed their villages and, to some extent, their province. In southern parts of the Netherlands either the feudal lords or the cities have dominated the villages to a large extent. Therefore, it is expected that the modern urban culture is more rapidly accepted by the farmers in the northern part of the Netherlands than in the southern part. Preliminary data from Wichers' research tend to confirm this hypothesis.

This study of Wichers is another illustration of the contribution history can make to explain norm differences and the rate of adoption of innovations. (History may even contribute to the formation of social-psychological theories; an example is the analysis of historical events by Baschwitz. He formulated a theory strinkingly similar to Festinger's dissonance theory, but published 34 years earlier(Brouwer, I962)).

\section{Extension uses of Diffusion Research}

Sociologists have not yet finished their task when they have analyzed the diffusion of innovations. They may give advice on ways to secure change. It is difficult to get innovations adopted in traditional communities. If a modern Extension agent tells a traditional peasant about new farming methods which are part of modern culture, it will be difficult for the peasant to integrate this message in his frame of reference. In the long run, the most effective way for an Extension agent to get his message through, is to change the total cultural pattern of the rural community. In other words, the task of the Extension agent is to educate people, rather than to promote farm innovations. This strategy is probably more generally accepted among U.s. than among Dutch Extension agents, but in the Netherlands, it comes mainly from sociological analysis, whereas in the U.s., it comes more from the psychology of learning.

If an Extension agent tells a farmer that he should change his behaviour, the farmer gains the impression that he is regarded as unintelligent and he defends himself against this attack by not accepting the Extension agent's recommendation. Some methods to solve this problem are now being tested in action research by social psychologists in the Netherlands. In individual farm visits, Carl 
Rogers' method of counseling is used by Extension agents, and nondirective group discussions may enable agents to reach traditional peasants not reached previously by the Extension Service (De Boer \& Prillevitz, I962; Goubitz, I959).

The social-psychological theories used in the Dutch Extension Service are mainly developed in the U.s. Surprisingly, U.S. social psychologists have given little attention to the problem of agricultural Extension and the adoption of new farm practices; an exception is a nearly 20 years old study of Likert \& Lippitt (I953). Perhaps it is because in U.s. universities, psychology is not taught in colleges of agriculture.

\section{Opinion Leadership}

In the Netherlands (as in the United States) personal influence is the main source of information at the evaluation stage in the adoption process. Sociometric techniques have been used to discover the farmers who exercise this influence in both countries. In the Netherlands (as in the drug study by Coleman, Katz and Menzel (I957) at Columbia University), three questions were asked:

I. Which two farmers would you ask for advice, if you were not sure whether a new practice will work on your farm or not?

2. Which two farmers do you consider as 'good farmers' in this community?

3. With which two farmers do you talk most often?

Farmers tend to select opinion leaders who are more innovative than themselves in answer to the second question, especially in modern communities. This tendency is very slight in answer to the third question. Perhaps this finding may explain the different results obtained by Katz and Lazarsfeld and by Lionberger and Coughenour (Lionberger, r960, p. 84ff.) as to the innovativeness of opinion leaders.

This finding also has implications for the two-step flow of communication hypothesis, which says that 'ideas often flow from radio and print to the opinion leaders and from these to the less-active sections of population'. Our research indicates that farmers who actively seek new ideas will probably go to those individuals they consider good farmers. Thus, a two-step process within the community results. In many cases, however, farmers obtain new ideas in an accidental way from those farmers to whom they talk most often. Then, a multistep flow seems more likely.

The two-step flow of communication hypothesis also needs revision 
on the basis of information sources used by leaders and followers. The original hypothesis stated that the leaders used the mass media as information sources, and their followers used more personal sources. U.s. research makes this hypothesis unlikely when it found that both early and late adopters used mass media at the awareness stage of the adoption process, and personal information at the evaluation stage(Beal \& Rogers, x 960, p. I6 and I9), Dutch research shows that this also holds true for both opinion leaders and their followers (Van den Ban, 1963 ). The weakness of the original statement of the two-sted flow is that it did not account for differences in communication sources on the basis of stage in the adoption process.

Research in both countries shows that in modern communities, opinion leaders are innovators, whereas they are early or late majority in traditional communities (Marsh \& Coleman, 1954; Young \& Coleman, 1959; Van den Ban, 1963). This can be explained from the theory of Homans (I96I) that leaders are individuals who provide scarce but valuable services to other group members.

All u.s. and Dutch studies have found a positive relationship between innovativeness and opinion leadership.

\section{Diffusion of Diffusion Research}

Although much attention in our paper has been centred around Netherlands studies, this certainly does not mean that U.s. research has not led in this field. Dutch research on diffusion would never have reached its present level without the work done by U.s. rural sociologists on the diffusion of farm innovations.

The communication of research findings and methods probably flows more efficiently from the U.s. to the Netherlands than vice versa, because all Dutch research workers can read and speak English, but few Americans are able to read Dutch.

Dutch rural sociologists must publish most of their results in Dutch, because interested action people find it easier to read Dutch than English. Some of the Wageningen bulletins have an English summary or are summarized in an English article. Because experience has taught that these methods are not sufficient to make Dutch sociological research known in other countries, a Dutch sociological journal in the English language will be published in the near future. 


\section{CONCLUSIONS}

A general criticism, of the rural sociology diffusion tradition in both countries, which has been voiced by rutal sociologists themselves (Lionberger, I960), is the lack of attention paid to sociological theory. Many diffusion studies approach raw empiricism with little emphasis upon the sociological significance of the findings.

The main theme of the present article is by now plain. Through improved 'diffusion' between the U.s. and the Netherlands of findings and methods, the quality of research on the diffusion of innovations in both countries can be raised. In the Netherlands, more attention could be given to building a theoretical model of the adoption of innovations - similar to Coughenour (I G62) and Emery (I962) - and to analyzing the relationship of farmer's goals and their cultural values (Wilkening \& Johnson, I96I). In the United States (and elsewhere), investigation of the relationship of the diffusion of new farm ideas with cultural norms will be fruitful. In fact, this type of research was advocated ten years ago (Sociological Research, 1952 ).

\section{REFERENCES}

BAN, A. W. VAN DEN ( $196_{3}$ ), Boer en landbouwvoorlichting: De communicatie van nieuwe landbouwmethoden (Assen, Neth.: van Gorcum).

BAN, J. P. A. VAN DEN (I96I), De traditionele boer. Landbouwvoorlichting, 18: 706-7IO.

BEAL, G. M. \& E. M. ROGERs (I960), The adoption of two farm practices in a central Iowa community (Ames: Iowa Agricultural Experiment Station), Special report 26.

Benvenutr, B. (I96r), Farming in cultural change (Assen, Neth.: van Gorcum) pp. 87ff.

Bergsma, R. (I963), Op weg naat een nieuw culturutpatroon (Assen, Neth.: van Gorcum).

Boer, J. DE \& F. C. PRILlevrtz (I962), Agratische sociale voorlichting: een groepsexperiment (Tiel, Neth.: Stichting tot Ontwikkeling van Komgrondengebieden).

Brouwer, M. (I962). Mass communication and the social sciences: some neglected areas. International Science Journal, I4: 303-3 I9.

Coleman, J. S., E. KaIZ \& H. Menzex (I957), The diffusion of innovations among physicians. Sociometry, 20: 253-270.

Cougrenour, C. M. (Ig60), 'The functioning of farmers' chatacteristics in relation to contact with media and practice adoption. Rural Sociology, 25: 284-297.

EMRRx, F. E. ( $(962)$, Heuristic model of the marketing process. Human Relations, Is: 63-76.

GermaNr, G. (1960), Secularización y desarrollo economico. In: Resistências à Mudanca (Rio de Janeiro: Centre Latino Americano de Pesquisas en Ciências Sociales) pp. 26I-279.

Goubizz, E. (1959), Gespreksvoering. Ned. Tijdschrift roor de Psychologie en haar Grensgebieden, $14: 485-503$. 
Groknman, S. (I947), Staphorst (Meppel, Neth.: Stenvert).

Horper, C. R. (I942), Acceptance of approved farming practices among farmers of Dutch descent (East Lansing, Michigan: Agricultural Experiment Station). Bulletin $3 \times 6$.

Homans, G. C. ( $196 \mathrm{x}$ ), Social behavior: its elementary forms. (New York: Harcourt, Brace and World).

KöNIG, R. (1962), Handbuch der empirischen Sozialforschung (Stuttgart: Enke).

Kollmorgen, W. M. (I94I), The German-Swiss in Franklin County, Tennessee: a study of the significance of cultural considerations in farming enterprise (Washington D.C.: B. A. E. Mimeo Bulletin).

LeRner, D. (I958), The passing of traditional society: modernizing the Middle East (New York: Free Press).

LrkerT, R. \& R. Lrppirt (1953), The utilization of social science. In: L. Festinger and D. Katz, Research methods in the behavioral sciences (New York: Dryden). esp. pp. $630-638$.

Lionberger, H.F. (I960), Adoption of new ideas and practices (Ames: Iowa State University Press).

Marsex, C. P. \& A. L. Coleman (I954), Fatmers' practice adoption rates in relation to the adoption rates of 'leaders'. Rural Sociology, I9: $180-183$.

Mendras, H. (I958), Les paysans et la modernisation de l'argiculture (Paris: Centre National de la Recherche Scientifique).

Rogers, E. M. (1958), Categorizing the adopters of agricultural practices, Rural Sociology 23: $345-354$.

- (I962), Diffusion of innovations (New York: Free Press).

RYAN, B. \& N. C. Gross (1943), The diffusion of hybrid seed corn in two lowa communities. Rural Sociology, 8: 15-24.

Sociological Research on the diffusion and adoption of new farm practices; Subcommittee on the diffusion and adoption of farm practices of the Rural Sociological Society (Lexington: Kentucky Agricultural Experiment Station) Mimeo Bulletin RS-2.

WiLkENing, E. A. \& D. E. Jorinson (I96I), Goals in farm decision-making as related to practice adoption (Wisconsin Agricultural Experiment Station) Research Bulletin 225.

WILson, M. C. \& G. Gallup (I955), Extension teaching methods and other factors that influence adoption of agricultural and home economics practices (Washington D.C. : USDA Federal Extension Service) Circular 495.

Wurzbacher, G. (I954), Das Dorf im Spannungsfeld industrieller Entwicklung (Stuttgart: Enke).

Young, J. N. \& A. L. ColEMAN (1959), Neighborhood norms and the adoption of farm practices. Rural Sociology, 24: 372-380. 
The introduction to this article serves as English summary.

\author{
RÉSUMÉ \\ RECHERCHE SUR LA DIFFUSION DES INNOVATIONS EN \\ AGRICULTURE AUX U.S.A. ET AUX PAYS-BAS
}

Des six "chaînes de recherches» sur la diffusion des innovations, analysées récemment (Anthropologie, Ethnologie, Sociologie Rurale, Sociologie de l'éducation, Sociologie industrielle, Sociologie médicale) c'est la sociologie rurale qui a fourni le plus grand nombre de publications et d'études sur la diffusion des idées nouvelles.

Un «chaîne de recherches» est une série d'études sur un sujet semblable dans laquelle chacune des études est influencée par la précédente.

Le but du présent article est de fournir une analyse comparée de deux sous-chaines de la sociologie rurale: La recherche portant sur la diffusion faite d'une part aux U.S.A., d'autre part aux Pays-Bas. L'accent est mis sur le développement historique de cette recherche dans les deux pays et sur la différence des méthodes employées.

Une attention particulière est donnée aux recherches néerlandaises, mal connues hors de ce pays, en raison des difficultés linguistiques.

\title{
ZUSAMMENFASSUNG
}

FORSCHUNGEN ÜBER DIE VERBREITUNG VON NEUERUNGEN IN DER LANDWIRTSCHAFT IN DEN VEREINIGTEN STAATEN UND DEN

NIEDERLANDEN

Bei der Analyse von sechs sogenannten 'Forschungstraditionen' die Verbreitung von Neuerungen betreffend (Anthropologie, frühe Soziologie, ländliche Soziologie, Erziehungs-, Industrie- und MedizinSoziologie) ergab sich, daß die ländliche Soziologie die größte Zahl von Publikationen und Studien über die Verbreitung neuer Ideen vorgelegt hat. Unter 'Forschungstradition' wird eine Serie von Studien über denselben Gegenstand verstanden, wobei nachfolgende Untersuchungen von den vorher gegangenen beeinflußt worden sind. Ziel des vorliegenden Berichtes ist eine vergleichbare Analyse von 
zwei 'Subtraditionen' innerhalb der ländlichen Soziologie, nämlich der Forschung über die Verbreitung von Neuerungen (I) in den Vereinigten Staaten und (2) in den Niederlanden. Besondere Betonung wird auf die historische Entwicklung dieses Gebietes in beiden Ländern und auf die Unterschiede in den Forschungsmethoden gelegt. Die Forschung in den Niederlanden wird etwas eingehender behandelt. Sie ist infolge der Sprachschranken außerhalb dieses Landes wenig bekannt. 